\title{
Anthropogenic sulfate and Asian dust signals in snow from Tien Shan, northwest China
}

\author{
Cameron P. Wake, Paul A. Mayewski, \\ Glacier Research Group, Institute for the Study of Earth, Oceans and Space, University of New Hampshire, \\ Durham, NH 03824, U.S.A. \\ Wang Ping, Yang QinzhaO*, Han Jiankang and Xie Zichu \\ Lanzhou Institute of Glaciology and Geocryology, Academia Sinica, Lanzhou 730000, China
}

\begin{abstract}
Snow samples were collected from a $0.5 \mathrm{~m}$ snowpack at Glacier No. 1 and near Bogda Feng, eastern Tien Shan, northwest China. Samples that were melted in the field were analyzed for chloride, nitrate, sulfate, sodium, potassium, magnesium, calcium, and microparticles. Eight samples were returned frozen and were analyzed for the above ions plus ammonium, acetate, formate, methylsulfonate, and hydrogen peroxide. There was no significant difference in measured major ion concentrations between the melted and frozen samples. Measured cations in both sets of samples were two to three times greater than measured anions. Calcium and sodium are the dominant cations while sulfate is the dominant measured anion. High ion burdens are associated with dusty layers in the snowpack, indicating that dust from the vast arid regions of central Asia is the dominant source for major ions in Tien Shan snow. The significant increase in sulfate and decrease in the cation: anion ratio in Bogda Feng snow relative to Glacier No. 1 snow suggest that anthropogenic emissions from Ürümqi are an important source of sulfate to precipitation downwind from the city.
\end{abstract}

\section{INTRODUGTION}

The chemical composition of precipitation in eastern China is strongly influenced by fossil fuel combustion as well as agricultural and cultural practices. The primary source for the high levels of sulfate measured in precipitation is the oxidation of sulfur dioxide released during combustion of coal in small- and medium-sized furnaces and coal-burning stoves (Zhao and Sun, 1986; Galloway and others, 1987). However, few measurements of the chemical composition of precipitation in western China have been undertaken. The vast extent of glacierized area and thick seasonal snowpacks in the high mountains of western China provide several locations from which to recover continuous, highresolution precipitation chemistry records without the expense and effort required to operate continuous monitoring stations.

The collection and chemical analysis of snow samples recovered over a wide spatial area have already proven extremely useful for determining, for example, the vertical separation of monsoonal and westerly derived air masses in northwest India (Mayewski and Lyons, 1983), the

* Present address: Glacier Research Group, Institute for the Study of Earth, Oceans and Space, University of New Hampshire, Durham, NH 03824, U.S.A. influence of anthropogenic pollution on precipitation chemistry in Canada (Schmenauer and others, 1985; McBean and Nikleva, 1986), Greenland (Mayewski and others, 1987), the Soviet Union (Belikova and others, 1984), and Spitsbergen (Semb and others, 1984), and the spatial variation and sources of major ions in precipitation in central Asia (Wake and others, 1990), central Greenland (Mayewski and others, 1990) and the world (Lyons and others, 1990). Further, understanding the spatial variation in snow chemistry and determining the relative importance of local versus regional chemical inputs are fundamental steps in confidently identifying glacier basins from which representative long-term glaciochemical records can be recovered.

As part of an ongoing glaciochemical research program in the mountains of central Asia, snow samples were collected from two different watersheds in the Tien Shan mountain range of northwest China. The chemical composition of these samples shows the influence of Asian dust and anthropogenic emissions on levels of selected carbon, nitrogen, and sulfur species in snow from the Tien Shan.

\section{SITE DESCRIPTION}

Snow samples were collected from Glacier No. 1 at the headwaters of the Ürümqi River (hereafter referred to as 


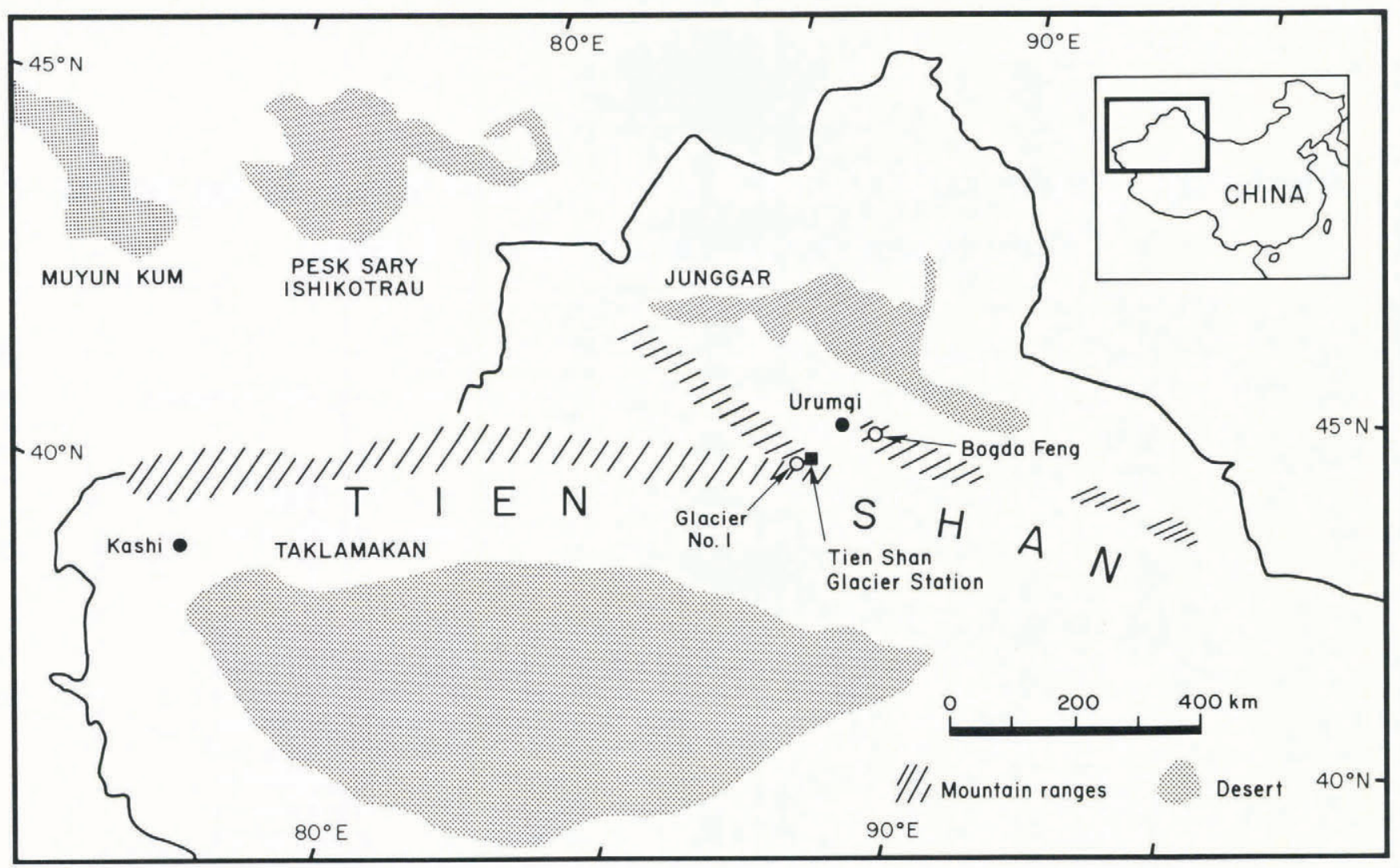

Fig. 1. Location of snow-sample collection sites at Glacier No. 1 and Bogda Feng, in the Tien Shan, northwest China. Note the large desert basins on the northern and southern margins of the Tien Shan.

Glacier No. 1) and near Bogda Feng. Both locations are in the eastern Tien Shan in northwest China; the sample sites are separated by $120 \mathrm{~km}$ (Fig. 1). The Tien Shan is bounded on the north by the Junggar, Pesk Sary Ishikotrau and Muyun Kum Deserts, on the south by the Taklamakan Desert and on the east by the Gobi Desert. Very little is known concerning the chemical composition of surface desert materials in this region (Dregne, 1968). The gravelly, medium- and fine-textured soils are probably calcareous. Soil salinity becomes greater toward and within deserts; many depressions within the deserts are very saline as a result of evaporation of water that collects in the depressions in spring (Dregne, 1968).

\section{Glacier No. 1}

Glacier No. 1 lies approximately $50 \mathrm{~km}$ northeast of the Rear Gorge (Houxia), which is the site of the Yaojin steel factory and a cement plant. Coal and iron are mined in the surrounding hills. Meteorological data from the Tien Shan Glaciological Station (5 km up valley from Houxia) indicates that daytime up-valley winds transport air from the Rear Gorge towards Glacier No. 1. Open valleys several hundred meters above the tree line characterize the headwaters of the Ürümqi River. Glacial coverage is limited to small cirque and hanging glaciers; the valley also holds extensive moraine deposits. Glacier No. 1 faces northwest and consists of two branches (east and west arms); its area is $1.84 \mathrm{~km}^{2}$.

\section{Bogda Feng}

Bogda Feng ( $5570 \mathrm{~m}$ a.s.l.) lies approximately $60 \mathrm{~km}$ west, and commonly downwind, from Ürümqi, which is a city of one million people and the economical and industrial center of Xinjiang Uygur Autonomous Region. Glaciers are restricted predominantly to the upper slopes of Bogda Feng. The open, glacier-free valleys to the northwest of Bogda Feng, where samples were collected, were covered with an $\approx 0.5 \mathrm{~m}$ deep snowpack in April 1989.

\section{METHODS}

\section{Sample collection}

Extreme care was taken at all times during sample collection, handling, transport, and analysis to assure sample integrity. Non-particulating clean suits and hoods, plastic gloves and particle masks were worn during all sampling procedures. Prior to use, all sample tools and containers were rinsed, soaked, and rinsed again with Millipore Milli- $Q^{\mathrm{TM}}$ deionized water. Analyses of duplicate samples as well as transport and laboratory blanks demonstrate that sample contamination during sample transfer, transport, and subsequent analytical procedures was negligible.

In mid-April 1989, samples of the entire seasonal snowpack $(\approx 0.5 \mathrm{~m}$ of snow) were recovered from snow pits excavated on the east and west arms of Glacier No. 1, 
Table 1. Snow samples collected from the Tien Shan for chemical analysis

\section{Date Elevation Number of samples}

m a.s.l.

Glacier No. 1.

snow pit 1

snow pit 2

11 April

3960

4140

12 April

Bogda Feng

snow pit 3

snow pit 4

16 April

3450

17 April

3550

samples were analyzed in duplicate using two separately drawn samples. This procedure resulted in a standard deviation from the mean of less than $5 \%$ for anions and less than $7 \%$ for cations. Microparticle concentrations over a size range of 0.65 to $12.88 \mu \mathrm{m}$ were measured using an Elzone 280PC particle counter.

Acetate $\left(\mathrm{CH}_{3} \mathrm{COO}^{-}\right)$, formate $\left(\mathrm{CHOO}^{-}\right)$, methanesulfonate $\left(\mathrm{CH}_{3} \mathrm{SO}_{3}{ }^{-}\right)$and hydrogen peroxide $\left(\mathrm{H}_{2} \mathrm{O}_{2}\right)$ analyses were undertaken only on frozen samples. Samples were analyzed for acetate, formate and methanesulfonate using a Dionex QIC ion chromatograph with a Dionex ${ }^{\mathrm{TM}}$ AS4 anion exchange column and a $0.4 \mathrm{mM} \mathrm{Na}_{2} \mathrm{CO}_{3}$ eluent. Peroxide was analyzed using the fluorometric technique described in Lazrus and others (1985).

\section{RESULTS}

\section{Physical stratigraphy}

The physical stratigraphy of the snowpack was similar at both sample locations even though the snowpack overlay glacier ice at Glacier No. 1 and ground at Bogda Shan. 0.15 to $0.20 \mathrm{~m}$ of snow from two separate snowstorms in early April (termed near-surface snow) lay on top of 0.30 to $0.50 \mathrm{~m}$ of depth hoar (Fig. 2). Two to three dust layers 10 to $20 \mathrm{~mm}$ thick were apparent in all four snow pits. At the elevations where snow samples were collected (Table 1) the entire snowpack melts during the summer ablation period.The snowpack in April, therefore, contained only snow deposited during winter 1988-89 and spring 1989, and thus represented approximately six months' accumulation. Total water equivalent of the snowpack varied from 0.10 to $0.17 \mathrm{~m}$.

\section{Chemistry of frozen samples}

The near-surface snow samples which remained frozen until just before analysis show a wide variation in concentration of chemical species measured (Table 2). However, much of the cation content is probably solubilized when the samples are melted. Total measured cations are two to three times greater than measured anions.

The ion balance of the frozen samples was calculated usıng the microequivalent per kilogram $\left(\mu \mathrm{Eq} \mathrm{kg}^{-1}\right)$ concentrations of all measured ions:

$$
\begin{aligned}
\Delta \mathrm{C}= & {\left[\mathrm{Na}{ }^{+}\right]+\left[\mathrm{NH}_{4}{ }^{+}\right]+\left[\mathrm{K}^{+}\right]+\left[\mathrm{Mg}^{2+}\right] } \\
+ & {\left[\mathrm{Ca}^{2+}\right]-\left[\mathrm{HCOO}^{-}\right]-\left[\mathrm{CH}_{3} \mathrm{COO}^{-}\right] } \\
& -\left[\mathrm{Cl}^{-}\right]-\left[\mathrm{NO}_{3}^{-}\right]-\left[\mathrm{SO}_{4}{ }^{2-}\right]
\end{aligned}
$$

Ammonium concentration in the frozen samples accounts for $75 \%$ of nitrogen measured and $12 \%$ of the total cation burden. Acetate and formate account for $8 \%$ of the total anion burden. Acetate displays a relatively constant concentration in the frozen samples while formate shows a wide range of concentrations which correlate well with variations in sulfate $\left(r^{2}=0.93 ; n=8\right)$. In snow samples with relatively high total ionic burden $\left(>300 \mu \mathrm{Eq} \mathrm{kg}^{-1}\right)$ 
Wake and others: Sulfate and dust signals in snow

$(\mu \mathrm{eq} / \mathrm{kg})$
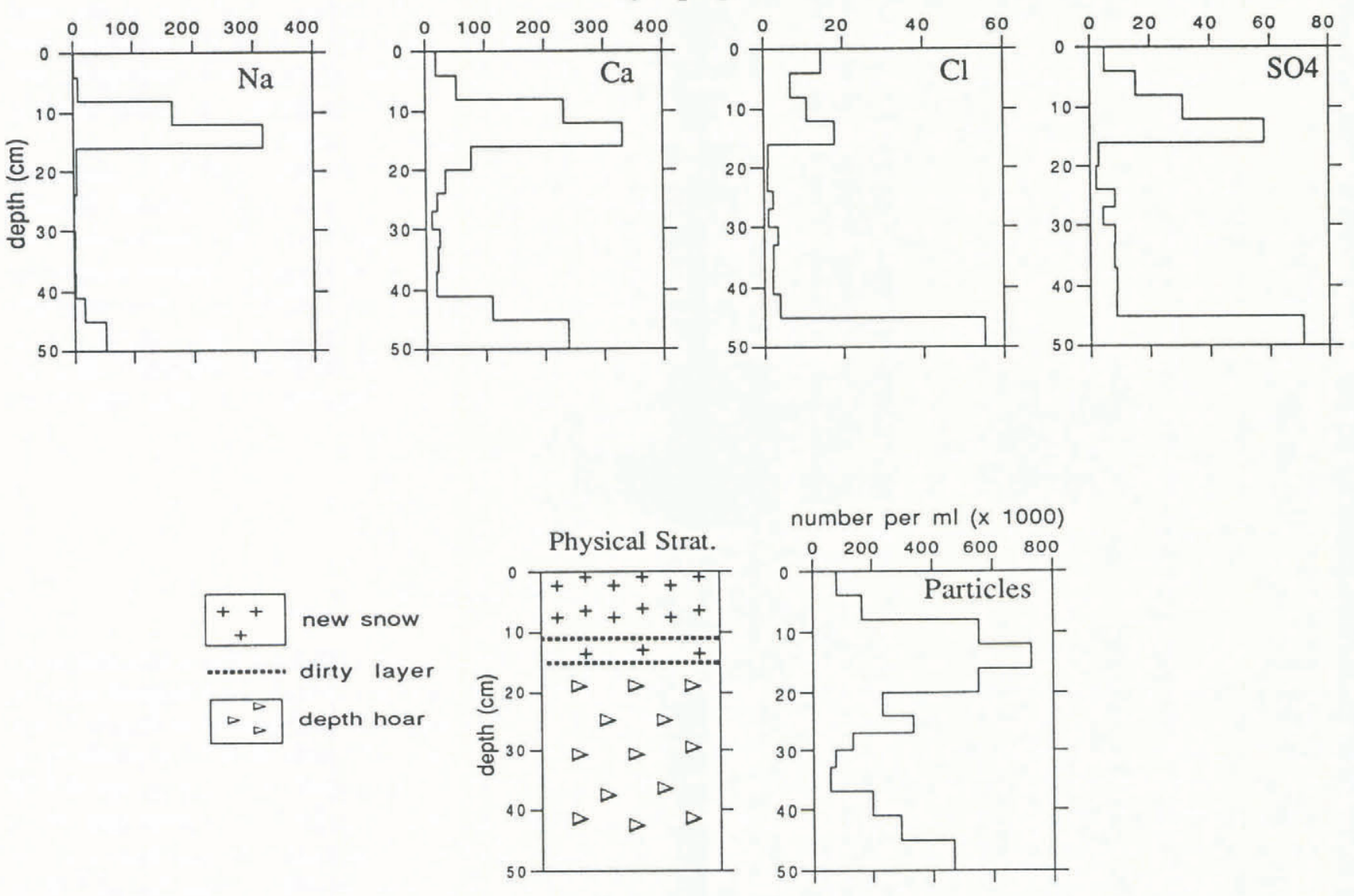

Fig. 2. Major ion concentration, physical stratigraphy, and microparticle concentration profiles in samples collected from snow pit no. 1 at $3960 \mathrm{~m}$ a.s.l. on the west arm of Glacier No. 1. Glacier ice underlay the $0.5 \mathrm{~m}$ snowpack. Note the strong correlation between high concentrations of $\mathrm{Na}^{+}, \mathrm{Ca}^{2+}$ and $\mathrm{SO}_{4}{ }^{2-}$ with high microparticle concentrations and visible dust layers in the snowpack.

Table 2. Ion concentrations in frozen samples of near-surface snow

\begin{tabular}{|c|c|c|c|c|c|c|c|c|c|c|c|}
\hline $\begin{array}{l}\text { Type of } \\
\text { snow }\end{array}$ & \multicolumn{10}{|c|}{ (ion concentration in $\mu \mathrm{Eq} \mathrm{kg}^{-1}$ ) } & $\begin{array}{c}\mathrm{H}_{2} \mathrm{O}_{2} \\
\mathrm{ppb}\end{array}$ \\
\hline dirty & 164 & 20.0 & 2.8 & 18.1 & 285 & 2.1 & 21.7 & 58.7 & 9.3 & 158 & 0.4 \\
\hline dirty & 226 & 24.4 & 3.6 & 20.6 & 243 & 1.9 & 22.2 & 69.1 & 11.3 & 206 & 0.4 \\
\hline dirty & 218 & 23.3 & 5.6 & 27.1 & 350 & 1.8 & 21.4 & 68.3 & 11.0 & 198 & 0.4 \\
\hline clean & 6.1 & 15.0 & 0.5 & 2.5 & 45.9 & 2.7 & 4.4 & 2.1 & 4.2 & 13.1 & 9.5 \\
\hline clean & 28.3 & 11.6 & 1.0 & 9.9 & 127 & 2.6 & 8.0 & 11.2 & 3.7 & 35.3 & 0.5 \\
\hline clean & 52.2 & 18.3 & 1.5 & 10.7 & 171 & 2.4 & 13.0 & 25.2 & 5.5 & 58.6 & 0.0 \\
\hline clean & 5.7 & 13.3 & 0.5 & 2.5 & 27.4 & 2.5 & 4.9 & 1.9 & 4.5 & 12.4 & 7.1 \\
\hline clean & 15.2 & 8.3 & 0.5 & 4.9 & 70.4 & 4.5 & 3.4 & 4.8 & 2.1 & 17.2 & 2.8 \\
\hline
\end{tabular}


formate concentrations are five to 10 times greater than acetate concentrations. In samples with lower ionic burdens, formate accounts for 40 to $60 \%$ of total acetate and formate load. Methanesulfonate was below the detection limit of 1 part per billion ( $\mathrm{ppb}$ ).

Hydrogen peroxide concentrations ranged from 0.0 to $9.5 \mathrm{ppb}$, and show a rapid decrease with increasing sulfate. Samples with relatively high sulfate $\left(>30 \mu \mathrm{Eq} \mathrm{kg}^{-1}\right)$ contain less than $0.5 \mathrm{ppb}$ hydrogen peroxide while samples with sulfate less than $20 \mu \mathrm{Eq} \mathrm{kg}^{-1}$ show hydrogen peroxide levels greater than $7.1 \mathrm{ppb}$.

\section{Chemistry of melted samples}

The results of chemical analysis for all snow-pit samples melted in the field $(\mathrm{n}=50)$ appear in Table 3. An ionic balance equation for the melted samples of the form

$$
\begin{gathered}
\Delta \mathrm{C}^{\prime}=\left[\mathrm{Na}^{+}\right]+\left[\mathrm{K}^{+}\right]+\left[\mathrm{Mg}^{2+}\right]+\left[\mathrm{Ca}^{2+}\right]- \\
{\left[\mathrm{Cl}^{-}\right]-\left[\mathrm{NO}_{3}{ }^{-}\right]-\left[\mathrm{SO}_{4}{ }^{2-}\right]}
\end{gathered}
$$

was used to determine the balance between measured cations and anions in each sample. This equation ignores the potential contribution from ammonium and organic acids; however, in the frozen samples, ammonium concentrations and combined acetate and formate concentrations were similar and therefore tend to cancel each other out.

In the melted samples, as in the frozen samples, the sum of major cations is two to three times greater than the sum of major anions. Among cations, calcium shows the the highest concentration followed by sodium. The predominant anions are represented by $\Delta C^{\prime}$ (Equation (2)) and sulfate.

Linear regression on all melted samples showed that calcium and magnesium correlate well $\left(r^{2}=0.97\right)$, as do calcium and $\Delta \mathrm{C}^{\prime}\left(\mathrm{r}^{2}=0.89\right)$ and magnesium and $\Delta \mathrm{C}^{\prime}$ $\left(r^{2}=0.91\right)$. Sodium correlates well with sulfate $\left(r^{2}=0.87\right)$. All other major anion-cation combinations show a positive correlation with $\mathrm{r}^{2}$ ranging from 0.55 to 0.70. All correlation coefficients are significant at the $\mathrm{P}=0.005$ level. In addition, high levels of sodium, calcium, chloride, and sulfate are associated with snow that was collected from a layer which contained visible dust and which had high microparticle concentrations relative to layers without visible dust (Fig. 2).

\section{DISCUSSION AND CONCLUSIONS}

\section{Frozen samples}

The high levels of ammonium are probably a result of widespread use of fecal remains as a fertilizer (Galloway and others, 1987) in the agricultural regions surrounding Ürümqi. Norton (1985) found that high levels of organic acids, especially formate ( $\approx 10$ to $100 \mu \mathrm{Eq} \mathrm{kg}^{-1}$ ), in precipitation downwind from large urban centers are related to anthropogenic emissions. The high formate levels measured in the frozen snow from Glacier No. 1 and Bogda Feng, and the good correlation between formate and sulfate, suggest that anthropogenic emissions are a source of both species in the eastern Tien Shan. The low levels of methanesulfonate in the snow suggest that biogenically produced dimethyl sulfide (DMS) is not a source of sulfur for this region (e.g. Legrand and others, 1988). Oxidation of sulfur dioxide can occur by reaction with hydrogen peroxide to produce sulfate (e.g. Penkett and others, 1979; Laj and others, 1990). A sharp drop in hydrogen peroxide levels in samples with high sulfate

Table 3. Measured major ion concentrations in snow-pit samples melted in the field

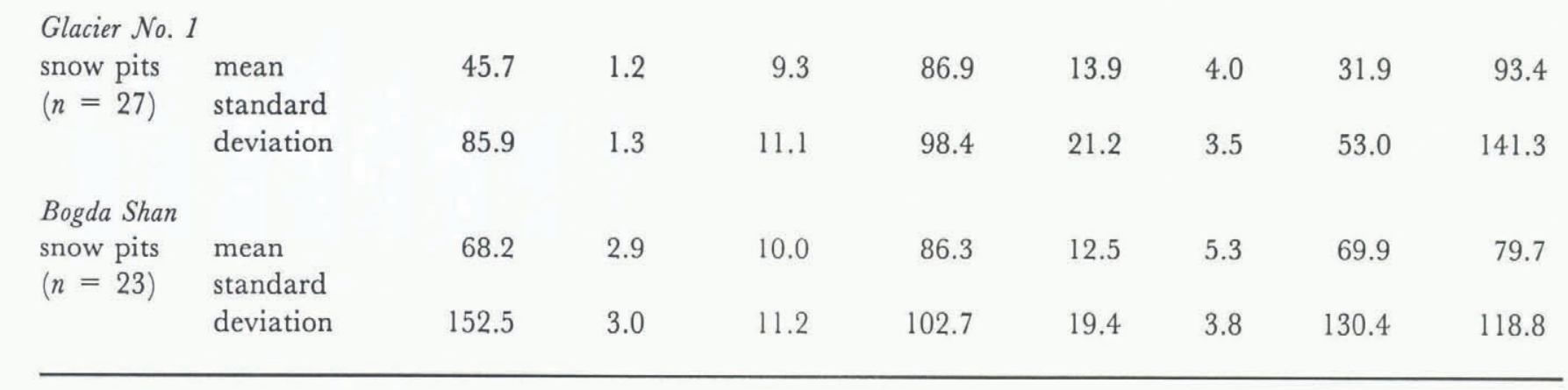

$\Delta \mathrm{C}^{* *}=\left[\mathrm{Na}^{+}\right]+\left[\mathrm{K}^{+}\right]+\left[\mathrm{Mg}^{2+}\right]+\left[\mathrm{Ca}^{2+}\right]-\left[\mathrm{Cl}^{-}\right]-\left[\mathrm{NO}_{3}{ }^{-}\right]-\left[\mathrm{SO}_{4}{ }^{2-}\right]$ 


\begin{tabular}{|c|c|c|c|c|c|c|c|c|c|}
\hline & \multirow{2}{*}{$\begin{array}{c}\Sigma^{\prime} \\
\mu \mathrm{Eq} \mathrm{kg}^{-1}\end{array}$} & \multicolumn{4}{|c|}{$\%$ of total cation charge } & \multicolumn{4}{|c|}{$\%$ of total anion charge } \\
\hline & & $\mathrm{Na}^{+}$ & $\mathrm{K}^{+}$ & $\mathrm{Mg}^{2+}$ & $\mathrm{Ca}^{2+}$ & $\mathrm{Cl}^{-}$ & $\mathrm{NO}_{3}^{-}$ & $\mathrm{SO}_{4}{ }^{2-}$ & $\Delta \mathrm{C}^{\prime}$ \\
\hline Glacier No. 1 & 286 & 16 & 1 & 9 & 74 & 12 & 7 & 23 & 59 \\
\hline Bodga Shan & 334 & 21 & 6 & 8 & 64 & 7 & 8 & 43 & 47 \\
\hline
\end{tabular}

Percentages were computed on a sample-by-sample basis and then averaged. Mean values may not add to $100 \%$ as a result of rounding.

$$
\Sigma^{\prime}=2\left\{\left[\mathrm{Na}^{+}\right]+\left[\mathrm{K}^{+}\right]+\left[\mathrm{Mg}^{2+}\right]+\left[\mathrm{Ca}^{2+}\right]\right\}
$$

suggests that oxidation of sulfur dioxide in northwest China occurs via reaction with hydrogen peroxide.

\section{Melted versus frozen samples}

Analysis of duplicate melted and frozen snow samples indicates there is little difference in the concentration of dominant ions (i.e. sodium, magnesium, calcium, chloride, nitrate, and sulfate) between samples that were melted in the field and those that were kept frozen until just prior to analysis (Fig. 3). Magnesium shows a slight enrichment in the melted samples in six out of eight cases (i.e. ratio greater than 1, Fig. 3); calcium displays a slight depletion in the melted samples in six out of eight cases. However, there exists no consistent trend of enrichment or depletion of any individual ion in the samples that were melted. In fact, the mean ratio for ion concentration in melted and frozen samples falls within one standard deviation of 1 for all ions. This improves our confidence not only in the major ion-concentration data from melted samples presented in this paper, but also in the chemical data from snow collected in the past at several different sites in the mountains of central Asia (Wake and others, 1990).

\section{Glacier No. 1 snow}

The total ionic charge $\left(\Sigma^{\prime}\right)$ for the melted samples from Glacier No. 1 was calculated using:

$$
\Sigma^{\prime}=2\left\{\left[\mathrm{Na}^{+}\right]+\left[\mathrm{K}^{+}\right]+\left[\mathrm{Mg}^{2+}\right]+\left[\mathrm{Ca}^{2+}\right]\right\}
$$

This calculation ignores the contribution from ammonium which accounts for $\approx 10 \%$ of the total cation burden in the frozen samples. $\Sigma^{\prime}$ is therefore considered a minimum estimate of the total ionic burden in the melted samples.

The percentage contribution of major cations and anions to the total cation and anion burden was determined for each individual sample; the mean values derived from this calculation appear in Table 4. For melted snow-pit samples from Glacier No. 1, calcium and sodium are the dominant cations, accounting for $74 \%$ and $16 \%$ of the total cation burden, respectively; $\Delta \mathrm{C}^{\prime}$ (Equation (2)) accounts for $59 \%$, and sulfate $23 \%$, of the total anion content.

Williams and others (1992) performed major ion and acid-neutralizing capacity (ANC) measurements on snow samples collected from Glacier No. 1 and surrounding
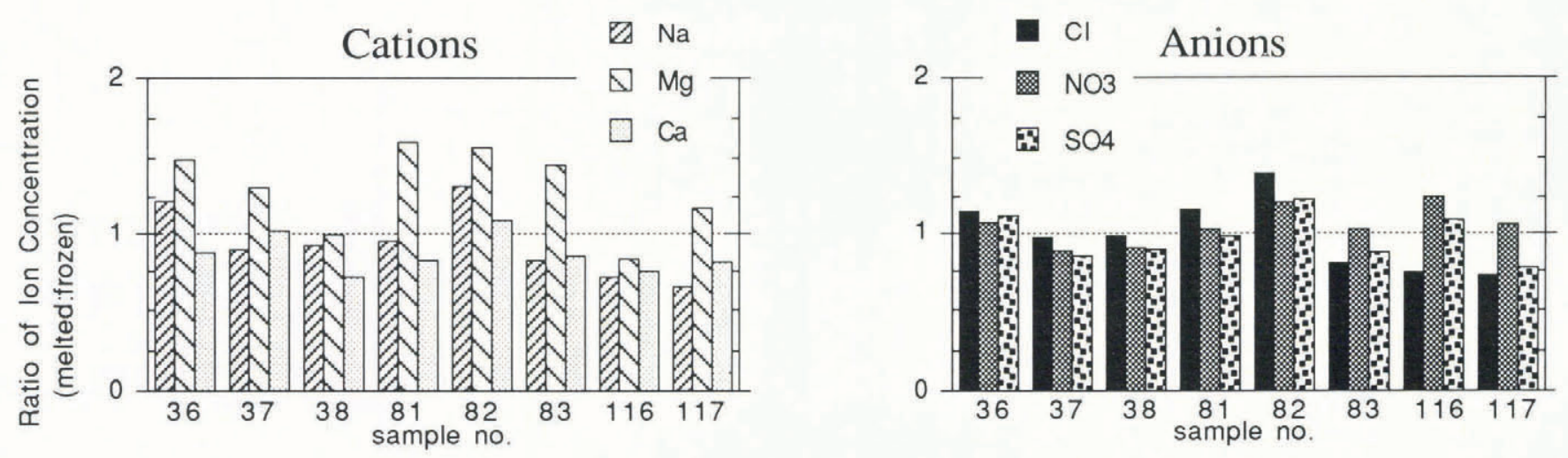

Fig. 3. Ratios of ion concentrations in melted and frozen samples. A ratio greater than 1 indicates that the ion concentration is greater in the sample melted in the field. Melted-to-frozen concentration ratios for all ions fall within one standard deviation of 1 . 


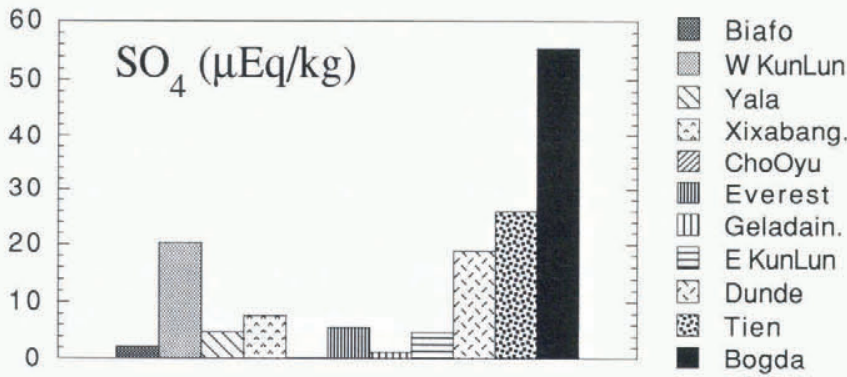

Fig. 4. Sulfate concentrations in snow from the mountains of central Asia. The sample sites are arranged roughly from west to east except for Glacier No. 1 (noted as "Tien" in figure) and Bogda Feng sites which lie to north of all other sample locations. For a description of the location and quality of snow samples collected from the Biafo Glacier, Yala Glacier, Mount Xixabangma and Mount Everest, see Wake and others (1990). The sulfate data from Cho Oyu, Mount Geladaindong, and the eastern Kunlun come from samples collected and analyzed by the Glacier Research Group. Data from the western Kunlun originates from an ice core recovered by a joint SinoJapanese program (Han and others, 1989); $12 \mathrm{~m}$ of core $B 12$ was sectioned and analyzed in GRG laboratories. The Dunde Ice Cap data come from Thompson and others (1989).

basins. The ANC in the snowpack comprised $61 \%$ of the total anion charge. This figure compares well with $\Delta \mathrm{C}^{\prime}$ (Equation (2)) contribution of $59 \%$ to the total anion burden in our snow samples (Table 4). Furthermore, Williams and others (1992) suggested that the source of ANC was dissolution of $\mathrm{CaCO}_{3}$ rich dust. The good correlation in our samples between calcium and $\Delta \mathrm{C}^{\prime}$, and the similarity between our $\Delta \mathrm{C}^{\prime}$ and $\mathrm{ANC}$ measured by Williams and others (1992), suggest that our $\Delta \mathrm{C}^{\prime}$ represents primarily carbonate/bicarbonate. The position of the Tien Shan relative to large desert basins with predominantly calcareous material (Dregne, 1968) provides strong evidence for a desert dust source of carbonate/bicarbonate in the snow.

The temporal variation in ion concentrations over approximately six months' precipitation (Fig. 2) tends to be much greater than spatial variation in ion concentrations over hundreds of kilometers (Table 3 ). This is consistent with the results of Williams and others (1992). The highest ion burden in the snowpack occurs in layers associated with visible debris and high microparticle content, suggesting that the large temporal variability (Fig. 2) in ion concentration is related to changes in the input of desert dust to the Tien Shan region.

The high levels of bases measured in Tien Shan snow (i.e $\Delta \mathrm{C}^{\prime}$, which we interpret as representing carbonate/ bicarbonate dissolution, and the relatively high ammonium concentrations measured in the frozen snow samples) indicate that the neutralizing capacity of the atmosphere is high in northwest China. This is similar to the situation in northeast China (Galloway and others, 1987).
The mean value for sulfate concentration in snow from Glacier No. 1 (Table 2) is among the highest sulfate levels measured in snow from the mountains of central Asia (Fig. 4 and Wake and others, 1990). The high sulfate content in Glacier No. 1 snow combined with an anthropogenic source of sulfate originating from the nearby steel factory suggests that anthropogenic emissions account for at least a portion of sulfate deposited in this region; however, with the available data, this is difficult to quantify.

\section{Bogda Feng snow}

While the ratio of measured cations to anions in Glacier No. 1 snow is 3.3, the ratio in Bogda Feng snow is only 1.8. This large variation in cation: anion ratio is not due to a decrease in cation concentrations in Bogda Feng snow; rather, it is a result of a doubling of sulfate levels in Bogda Feng snow (Table 2). As with snow from Glacier No. 1, calcium and sodium are the dominant cations, accounting for $64 \%$ and $21 \%$ of $\Sigma^{+}$, respectively. However, sulfate accounts for a greater percentage of $\Sigma^{-}$ in Bogda Feng snow compared to snow from Glacier No. 1 (Table 4 ). ( $\Delta \mathrm{C}^{\prime}$ in Table 4 for Bogda Feng snow was calculated using Equation (2). However, we expect that, for ions listed in Equation (2), $\Sigma^{-}$is actually greater than $\Sigma^{+}$as a result of the influx of sulfate. Unfortunately our data are not detailed enough to determine the excess anions with an acceptable degree of certainty.)

Among all the major ions, only sulfate displays a significant difference between snow-pit samples collected from Glacier No. 1 and Bogda Feng (Student's $t$ test; confidence interval $=0.90)$. All other major ions, as well as $\Sigma^{+}$, show no significant difference between the Glacier No. 1 and Bogda Feng samples, even at a confidence interval as low as 0.70 . Only half of the increase of sulfate in Bogda Feng snow can be accounted for by increased dust input (i.e. increase in $\mathrm{Na}$ concentration; Table 2). Snow from Bogda Feng contains two to 10 times more sulfate than has been measured in snow from several other mountain regions in central Asia (Fig. 4). The high values of sulfate in Bogda Feng snow compare well with sulfate levels in polluted snow surrounding major industrial regions in the USSR (Belikova and others, 1984). The position of Bogda Feng, $60 \mathrm{~km}$ downwind from Ürümqi, combined with the very high levels of sulfate in snow from this region are indicative of an anthropogenic source for a portion of the sulfate in Bogda Feng snow.

Snow from the western Kunlun and the Dunde Ice Cap show mean sulfate concentrations of 20.3 and 18.9, respectively (Fig. 4). These levels of sulfate, in addition to those in snow from Glacier No. 1 and Bogda Feng, are much higher than in any other snow samples recovered from the mountains of central Asia (Fig. 4 and Wake and others, 1990). While the Glacier No. 1 and Bogda Feng sites lie adjacent to centers of anthropogenic emissions, which in part contribute to the observed high levels of sulfate, the western Kunlun and Dunde Ice Cap sites are distant from any major industrial center. The position of the western Kunlun and the Dunde Ice Cap adjacent to large desert basins, (the Tarim basin to north of western Kunlun and the Qaidam basin to west of Dunde Ice Cap), suggests that the high sulfate levels are a result of an 
influx of desert-derived material. This, in turn, suggests that glaciochemical records recovered from these regions are difficult to interpret in terms of regional atmospheric chemistry due to swamping of regional chemical signals by local desert-derived materials.

\section{AGKNOWLEDGEMENTS}

We thank all members from the Lanzhou Institute of Glaciology and Geacryology who helped during our sample collection program in the Tien Shan. Dr Robert Talbot graciously conducted the acetate, formate and methanesulfonate analyses, Scott Drummy kindly provided the hydrogen peroxide analyses, and Joe Fiacco conducted the microparticle analysis. We thank Sallie Whitlow for invaluable assistance with major ion analyses and subsequent data reduction. Jack Dibb and an anonymous reviewer provided helpful suggestions.

\section{REFERENGES}

Belikova, T. V., V.N. Vasilenko, I. M. Nazarov, A. N. Pegoyev and Sh. D. Fridman. 1984. Characteristics of background sulfate pollution of the snow cover on the territory of the USSR. Meteorol. Hydrol., 9, 36-43.

Dregne, H.E. 1968. Surface material of desert environments. In McGinnies, W. G., B.J. Bram and P. Paylore, eds. Deserts of the world. Tucson, AZ, University of Arizona Press, 287-377.

Galloway, J. N., D. Zhao, J. Xiong and G. E. Likens. 1987. Acid rain: China, United States and a remote area. Science, 236, 1559-1562.

Han Jiankang, Zhou Tao and M. Nakawo. 1989. Stratigraphic and structural features of ice cores from Chongce Ice Cap, west Kunlun mountains. Bull. Glacier Res. 7, 21-28.

Laj, P., S. M. Drummey, M.J. Spencer, J. M. Palais and H. Sigurdsson. 1990. Depletion of $\mathrm{H}_{2} \mathrm{O}_{2}$ in a Greenland ice core: implications for oxidation of volcanic $\mathrm{SO}_{2}$. Nature, 346(6279), 45-48.

Lazrus, A. L., G. L. Kok, S. N. Gitlin and J.A. Lind. 1985. Automated fluorometric method for hydrogen peroxide in atmospheric precipitation. Anal. Chem., 57, 917-922.

Legrand, M. and C. Saigne. 1988. Formate, acetate and methanesulfonate measurements in Antarctic ice: some geochemical implications. Atmos. Environ., 22(5) 10111017.

Lyons, W. B., P.A. Mayewski, M.J. Spencer and M.S. Twickler.1990. Nitrate concentrations from remote areas: implications for the global NOx flux. Biogeochemistry, 9, 211-222.

McBean, G. A. and S. Nikleva. 1986. Composition of snow in Pacific coastal mountains. Atmos. Environ., 20(6), 1161-1164.

Mayewski, P.A. and W.B. Lyons. 1983. Chemical composition of a high altitude fresh snowfall in the Ladakh Himalayas. Geophys. Res. Lett., 10(1), 105-108.

Mayewski, P.A., M.J. Spencer, W. B. Lyons and M. S. Twickler. 1987. Seasonal and spatial trends in south Greenland snow chemistry. Atmos. Environ., 21(4), 863869.

Mayewski, P.A., M.J. Spencer, M.S. Twickler and S. Whitlow. 1990. A glaciochemical survey of the Summit region, Greenland. Ann. Glaciol., 14, 186-190.

Norton, R. B. 1985. Measurements of formate and acetate in precipitation at Niwot Ridge and Boulder, Colorado. Geophys. Res. Lett., 12(11), 769-772.

Penkett, S. A., B. M.R. Jones, K. A. Brice and A. E.J. Eggleton. 1979. The importance of atmospheric ozone and hydrogen peroxide in oxidizing sulfur dioxide in cloud and rainwater. Atmos. Environ., 13, 139-147.

Thompson, L. G. and 9 others. 1989. Holocene-Late Pleistocene climatic ice core records from QinghaiTibetan Plateau. Science, 246(4929), 474-477.

Schemenauer, R.S., P.W. Summers, H.A. Wiebe and K. G. Anlauf. 1985. Spatial and temporal variability of surface snowfall and snowpack chemistry in central Ontario. Ann. Glaciol., 7, 185-190.

Semb, A., R. Brækkan and E. Joranger. 1984. Major ions in Spitsbergen snow samples. Geophys. Res. Lett., 11(5), 445-448.

Wake, C. P., P. A. Mayewski and M.J. Spencer. 1990. A review of central Asian glaciochemical data. Ann. Glaciol., 14, 301-306.

Williams, M.A., K.A. Tonnessen, J. M. Melack and Yang Daqing. 1992. Sources and spatial variation of the chemical composition of snow in the Tien Shan, China. Ann. Glaciol., 16, 25-32.

Zhao, D. and B. Sun. 1986. Air pollution and acid rain in China. Ambio, 15(1), 2-5.

The accuracy of references in the text and in this list is the responsibility of the author/s, to whom queries should be addressed. 